\title{
Reading the World: Literary Studies in the 80s
}

After MY PUblic Lecture on "Literature and Life" in March 1980 at the Riyadh University Center for Girls [sic], a student asked me with some asperity: "It's all very well to try to live like a book; but what if no one else is prepared to read? What if you are dismissed as an irresponsible dreamer?" I found an answer to her question at the tail end of a metaphor: "Everyone reads life and the world like a book. Even the so-called 'illiterate.' But especially the 'leaders' of our society, the most 'responsible' nondreamers: the politicians, the businessmen, the ones who make plans. Without the reading of the world as a book, there is no prediction, no planning, no taxes, no laws, no welfare, no war. Yet these leaders read the world in terms of rationality and averages, as if it were a textbook. The world actually writes itself with the many-leveled, unfixable intricacy and openness of a work of literature. If, through our study of literature, we can learn ourselves and teach others to read the world in the 'proper' risky way, and to act upon that lesson, perhaps we literary people would not forever be such helpless victims." It is difficult to say that very last bit to a woman in Saudi Arabia. So I added, half to myself, and with a sense of failure: "Mere literary studies cannot accomplish this. One must fill the vision of literary form with its connections to what is being read: history, political economy - the world. And it is not merely a question of disciplinary formation. It is a question also of questioning the separation between the world of action and the world of the disciplines. There is a great deal in the way."

In that exchange I was obliged to stress the distinction between my position and the position that, in a world of massive brutality, exploitation, and sexual oppression, advocates an aesthetization of life. Here I must stress that I am also not interested in answers to questions like "What is the nature of the aesthetic?" or "How indeed are we to understand "life'?" My concern rather is that: 1) The formulation of such questions is itself a determined and determining gesture. 2) Very generally speaking, literary people are still caught within a position where they must say: Life is brute fact and outside art; the aesthetic is free and transcends life. 3) This declaration is the condition and effect of "ideology." 4) If "literary studies" is to have any meaning in the coming decade, its ideology might have to be questioned.

If the student and critic of literature is made to believe in and to perpetuate the

Gayatri Chakravorty Spivak teaches English at the University of Texas at Austin. She delivered this talk to the association of Departments of English in June 1980.

College English

Vol. 43, No. $7 \bullet$ November 1981 
received dogma of my second point, then the work of the "world" can go on without the interference suggested in my fourth point. But the disciplinary situation of the teacher of literature is inscribed in that very text of the "world" that the received dogma refuses to allow us to read. As a result, even as in classroom and article we mouth the freedom of the aesthetic, in bulletin and caucus and newspaper and meeting we deplore our attenuation and betrayal by society. The effort to invite a persistent displacement of the bewildering contradiction between life and art relates to the displacement of the bewildering contradiction between the conditions of life and the professions of our profession.

I have recently described our unwitting complicity with a world that efficiently marginalizes us in the following way:

We are the disc jockeys of an advanced technocracy. The discs are not "records" of the
old-fashioned kind, but productions of the most recent technology. The trends in taste
and the economic factors that govern them are also products of the most complex interre-
lations among a myriad factors such as foreign relations, the world market, the conduct
of advertisement supported by and supporting the first two items, and so on. To speak of
the mode of production and constitution of the radio station complicates matters further.
Within this intricately determined and multiform situation, the disc jockey and his audi-
ence think, indeed are made to think, that they are free to play. This illusion of freedom
allows us to protect the brutal ironies of technocracy by suggesting either that the system
nourishes the humanist's freedom of spirit, or that "technology," that vague evil, is some-
thing the humanist must transform by inculcating humanistic "values," or by drawing
generalized philosophical analogies from the latest spatio-temporal discoveries of the mag-
ical realms of "pure science." "Explanation and Culture: Marginalia," Humanities in Soci-
ety, 2, No. 3 [1979], p. 209; modified)

In the context of this marginalization our in-house disputes seem not only trivial but harmful. I refer, of course, to the disputes between composition and literature, and between practical criticism/literary history and "theory."

In the case of the dispute between composition and literature, the bewildering contradiction I speak of above is clearly to be seen. Teaching composition is recognized inside and outside the academy to be socially useful. If indeed the pages of the $A D E$ Bulletin are to be believed, since 1976 the number of jobs in composition has doubled, and the area has held steady as the largest provider of jobs in the profession. Yet in terms of the politics and economics of the university, the college, the department, and the profession, it is the composition teacher whose position-with some significant exceptions-is less privileged and more precarious. The culprit is not far to seek. It is the received dogma of the freedom of the aesthetic and literature's refusal to soil itself by rendering service to the state-when that very refusal is the greatest service that it can render to a polity that must disguise the extraction of surplus value as cultural dynamism.

Although my general argument and my metaphor of the humanist as disc jockey directly question this illusion of freedom from the "world" and the state, it is in the matter of the dispute between theory and practical criticism/literary history that I find myself most directly touched. I should of course admit that my concern reflects my own increasing specialization in "theory." (By "theory" is meant un-American activities that employ a vocabulary and sometimes methods belonging to the history of ideas rather than strictly to the domain of literary criticism, such as those of phenomenology, structuralism, deconstruction, semiotics. "Psychological" and 
"Marxist" criticism, long accused of reductivism and determinism, have entered "theory" through Jacques Lacan, Louis Althusser, and the Frankfurt School. The preferred and "American" side of the dispute endorses "pluralism," according to which some points of view are clearly delineated as more equal and more fundamental than others. The terms can be seen outlined in such exchanges as "The Limits of Pluralism," M. H. Abrams, Wayne Booth, J. Hillis Miller, Critical Inquiry, 3 [1977], 407-447; such works as Gerald Graff's Literature Against Itself: Literary Ideas in Modern Society, [Chicago: University of Chicago Press, 1979]; and such forums as most of the "theoretical" sessions at annual conventions of national or regional literary organizations.)

Unfortunately enough, what I call the received dogma of the discipline of literary study affects the so-called theoretical field and the so-called practical-historical field equally. The two sides of the dispute in fact leave our general marginalization intact. When "theory" brings up questions of ideological "interest," or the limitations of the merely aesthetic norm, the terminology becomes fearfully abstract. On the other hand, when "theory" seeks to undo this situation by attempting a reading of a hidden ethical or ideological agenda in a literary text, a curious topos rises up to resist: the critic is accused, if only by implication, of being a charlatan, of playing Pied Piper to the young, while mature wisdom consists in leaving Business as Usual.

I was troubled by this at our own conference when, after an excellent talk on the resources and techniques for getting grants in our profession, Professor Steven Weiland remarked about Robert Scholes' performance the previous night: "I confess that the paragraph I am about to quote could perhaps be read to mean quite another thing by a semiotician. I suppose I am just not young enough to be able to learn that sort of reading." (I cannot quote his exact words, of course. It was an unrehearsed aside. Scholes had attempted a delicate reading of the theme of the inexhaustible volubility of nonintellectual women as a topos of masculinist ideology as it operates in the discourse of Hemingway's "A Very Short Story.")

The same veiled accusation appears at the end of Denis Donaghue's ill-considered review of the most notorious "theory" stalking the halls of American literary criticism today-“deconstruction": "I think Deconstruction appeals to the clerisy of graduate students, who like to feel themselves superior to the laity of common readers" ("Deconstructing Deconstruction," The New York Review of Books, 27, No. 10 [1980], p. 41).

The fear of a critical reading that would question the writer's direct access to his or her meaning is related to the received dogma of the illusion of freedom. Strictly speaking, received dogma is another name for ideology. Ideology in the critical sense does not signify an avowed doctrine. It is rather the loosely articulated sets of historically determined and determining notions, presuppositions, and practices, each implying the other by real (but where does one stop to get a grip on reality?) or forced logic, which goes by the name of common sense or self-evident truth or natural behavior in a certain situation. What $I$ have been talking about so far has been the displacing of the ideology of our discipline of literature.

Such an effort need not involve questioning the individual good will of author or critic. The fear of critical reading ill-concealed in the following words is what an ideology-critical pedagogy would constantly question: "The wretched side of this is that Deconstruction encourages [graduate students] to feel superior not only to un- 
dergraduates but to the authors they are reading" (Donaghue, p. 41). Wasn't it the "intentional fallacy" that did that? "Wordsworth's Preface to the Lyrical Ballads is a remarkable document, but as a piece of Wordsworthian criticism nobody would give it more than about a B plus" (Northrop Frye, Anatomy of Criticism: Four Essays [Princeton: Princeton University Press, 1957], p. 5).

A pedagogy that would constantly seek to undo the opposition between the verbal and the social text at the same time that it knows its own inability to know its own ideological provenance fully is perhaps better understood in the American context as a de-archaeologized and de-teleologized version of the Baconian project to discover the idols of the mind, which would constitute rather than lead to, in a fragmented rather than continuous way, a New Philosophy or Active Science. ${ }^{1}$ It is an experiment in using an expertise in reading literature to read the text of a world that has an interest in preserving that expertise merely to propagate, to use the Baconian word, an idolatry of literature, perhaps even a species of self-idolatry as the privileged reader.

Rather than continue in this abstract vein, let me beguile you with some examples.

I taught a seminar for first-year Plan II students at the University of Texas last fall. Plan II is an interdisciplinary, four-year honors program for exceptionally gifted liberal arts undergraduates; everything else in the college is Plan I.

At the first class meeting, the young men and women sat, as did I, in movable chairs around a hollow square of four oblong tables. I was a little late for the second class meeting. The students had left the same chair empty, and thus given me a chance to introduce to them the theme that is my subject tonight. Here is a gist of my homily: "You are amazingly intelligent young people of unquestionable personal good will. The university has rightly rewarded your outstanding merit by adjudicating some extra freedoms for you. You have, for example, been granted a serious degree of freedom by the arrangement of furniture. You sit with your teacher in a small group in movable chairs around a center; your less gifted peers are in large, well-monitored classes in fixed seats gazing upon authority on a dias. But history and the institutions of power and authority are stronger than the limits of personal good will. If you deny them, they will get in through the back door. Because I warmed that particular chair with my bottom the last time, I seem to have baptized it as the seat of authority and you have left it empty for me. Your historicalinstitutional imperatives are proving stronger than your personal good will. Since

\footnotetext{
${ }^{1}$ I apologize for this awkward sentence. The production of language is our practice. The received dogma asks that our language be pleasant and easy, that it slip effortlessly into things as they are. Our point of view is that it should be careful, and not take the current dogmatic standard of pleasure and ease as natural norms. As for Bacon, I am rueful that, given his spotty record, that is the best one can do for the American literary-critical sensibility. As Stuart Hall has argued, "The concept of 'ideology' has never been fully absorbed into Anglo-Saxon social theory. . . . An interesting essay could be written on what concepts did duty, in American social theory, for the absent concept of 'ideology': for example, the notion of norms in structural functionalism, and of 'values' and the 'central value system' in Parsons" ("The Hinterland of Science: Ideology and the 'Sociology of Knowledge," Working Papers in Cultural Studies, 10 [1977], p. 9). As for the "New Philosophy," I hastily disclaim any connection with the young philosophical aesthetes in Paris whose passionate effusions are sometimes known by that name. It is "active" that I want to stress, and "science" in the sense of "state or fact of knowing" (OED).
} 
our topic this semester is going to be 'Images of Woman and Man in the Texts of Men and Women,' what I am saying now might be useful for us. We will read some great texts of the past-such as The Eumenides, The Vita Nuova, and Émile-and see in them the blueprints for rather questionable sexual attitudes. Now you must remember, every day in class, and as you write your papers, that this is not to belittle Aeschylus, Dante, or Rousseau as individuals, but to see in and through them something like their 'age,' to take into account how we are ourselves caught in a time and a place, and then to imagine acting within such an awareness."

I made some good friends in that class-although I could not always be sure of a chair if I was late-partly because they saw repeatedly that the readings advanced by their teacher, that figure of authority, were not authoritatively backed up by the traditional readings of, say, Aeschylus, or Dante, or yet Rousseau. There was, however, a certain problem the class could not get over.

Since our theme was so clearly socio-historical, I would often ask these students to write their papers from a point of view that was not only that of private but also of public individuals. After a variety of valiant efforts, nearly every paper faced with that specific charge ended in variations of the following argument: In the final analysis, no public generalization of this question is possible or even desirable, because we are all unique individuals.

I think I had made it clear to my students that, although I was often critical of European or American ideology, I was in no way at all offering them, as a native of India, a so-called "Indian spiritual" solution. I was able to talk to them about the problem in their papers, therefore, in a dialogue resembling what follows:

"Do you know what indoctrination is?"

"Yes."

"Do you know where it is to be found?"

"The Soviet Union and the Islamic world."

"Suppose an outsider, observing the uniformity of the moves you have all sketched in your papers, were to say that you had been indoctrinated? That you could no longer conceive of public decision-making except in the quantified areas of your economics and business classes, where you learn all about rational expectations theories? You know that decisions in the public sphere, such as tax decisions, legal decisions, foreign policy decisions, fiscal decisions, affect your private lives deeply. Yet in a speculative field such as the interpretation of texts, you feel that there is something foolish and wrong and regimented about a public voice. Suppose someone were to say that this was a result of your indoctrination to keep moral speculation and decision-making apart, to render you incapable of thinking collectively in any but the most inhuman way?"

For my second example I will go back to Saudi Aradia, this time to the male faculty of the Riyadh University Faculty of Arts. I met a group of faculty members twice-I think it was the first time a woman had run what amounted to a faculty development seminar there. The impression I carried away strengthened my conviction about not only literature, but the humanities in general in the service of the state.

Since 1973, Saudi Arabia has been one of America's strongest allies among the OPEC countries. As a result of the incredible boom following the surprise defeat of Israel that year, Saudi Arabia is "modernizing" itself at an extremely rapid pace. 
Part of the "modernizing" package is, quite properly, education; most of it, for reasons much larger than individual enthusiasm for American education, from the United States. As far as I could tell, the methodologies of the humanities that were being imported through visiting or U.S. trained faculty sustain and are sustained by the ideology or received dogma of disinterestedness and freedom that $I$ have been describing in the case of literature. I compiled this checklist while I was there: analytical and speech act theory in philosophy; quantitative analysis, structural functionalism, and objective structuralism in history and anthropology; mathematization on a precritical psychological model in linguistics; descriptive and biologistic clinical approaches, behaviorism, and delibidinized ego-psychology in psychology; objective structuralism, New Criticism, history- and ideology-transcendent aestheticism in literature-and so on. (I received such lavish hospitality from my hosts that it seems churlish to add that I had probably been invited to add to this package the message of Deconstruction American Style.)

Following my general viewpoint, I would not for a moment suggest that one or more evil geniuses here or in Saudi Arabia are necessarily planning this exportimport business in methodologies. My entire pedagogic approach would then come to nothing. The point is, first, that the ideological/material concatenation that produces this can be read and acted upon, although not once and for all, but rather constantly, persistently, like all repeated gestures of life-sustenance. Saudi Arabia, with American help, is in fact slowly fabricating for itself a "humanist" intellectual elite that will be unable to read the relationship between its own production and the flow of oil, money, and arms. A diversified technocratic elite whose allegiance to humanism, if at all in evidence, will be sentimental, will take care of those dirtier flows. The apparent lack of contact between rational expectations in the business world and freedom and disinterest in the humanist academy will support each other, as here, and to America's advantage. To call it "cultural imperialism" is to pass the buck, in every sense. I am attempting to suggest our pedagogic responsibility in this situation: to ask not merely how literary studies, more correctly the universitarian discipline of English studies, can adjust to changing social demands, but also how we could, by changing some of our assumptions, contribute toward changing those demands in the very long run.

An Arab-American linguist trained on the American West Coast asked me at one of the meetings in Riyadh, "How do you propose to fit, say, Shakespeare, into this pedagogic program?" I did give him an answer, in some detail, referring to my experience as a student in India and a teacher in the American Middle West and Texas. That reply will have to wait till next time. Let me, however, indicate that I have outlined an answer with reference to Wordsworth's The Prelude in an essay"Sex and History in Wordsworth's The Prelude (1805): Books Nine to Thirteen"forthcoming in Texas Studies in Language and Literature. ${ }^{2}$

The point of these far-flung digressions has been, then, that a literary study that can graduate into the $80 \mathrm{~s}$ might teach itself to attend to the dialectical and continu-

\footnotetext{
${ }^{2}$ Because the essay was too long, those pages outlining the argument were edited out. That decision in itself might provide food for thought on the norms of pertinence for scholarly journals. I hope to include the argument in my forthcoming book on theory and practice in the humanities.
} 
ous crosshatching of ideology and literary language. Further, that such an activity, learned in the classroom, should slide without a sense of rupture into an active and involved reading of the social text within which the student and teacher of literature are caught.

The after-dinner speech as genre allows me to add another story. Toward the beginning of May this year, Sir James Cavenham, the English financier, was looking to buy out " 35 percent of Diamond [International]'s stock." He already owned "nearly 6 percent." This was in opposition to Diamond's "proposed acquisition of Brooks-Scanlon Inc., a forest products company" [New York Times, 13 May 1980, Sec. 4, p. 4], because it would reduce Cavenham's share to a much smaller percentage. Diamond is a paper company.

"As the battle intensified," the Times reported next week, "Wall Street professionals eagerly watched the in-fighting on both sides. The highly respected Merrill Lynch Whiteweld Capital Market Group had assured Diamond a month ago that the merger terms were fair to Diamond's stockholders. The equally prestigious house of Warburg Paribas Becker gave the same assurance to Brooks-Scanlon investors." In the same issue of the Times, an advertisement covering an entire page exhorted Diamond's stockholders to vote "no" on the merger, assuring them that it would be to their benefit and advantage.

We have here what the latest literary theory would call-borrowing a word from the Greek-an aporia, an unresolvable doubt. We show our ideological acceptance of error-as-truth when we say, no, one is a paid ad, the other is news, the first therefore is more liable to be false. Is it? If the exchange of money allows for lie-astruth, what are Diamond, Brooks-Scanlon, Merrill Lynch, and Warburg Paribas Becker working in the interest of? Where is there a decidable truth free of the circuit of exchange to be found? What about the fact that most people would rather read the full-page ad and believe it than read the details of printed news and understand it? Has that fact anything to do with the self-marginalizing dogma of the teaching of literature? Is there an active-philosophical (to remind you of the Baconian term) analysis of that? On May 14, Diamond's annual meeting took place in Bangor, Maine, where Cavenham's French Company Générale Occidentale, S.A., planned to oppose the Brooks-Scanlon-Diamond merger. In nearby Orono, the International Association for Philosophy and Literature met from May 8 to 11. Considerable amounts of paper-Diamond's direct and Brooks-Scanlon's indirect product-were consumed. A considerable amount of intellectual energy and acrimony was spent on the work of a French philosopher who had suggested that "truth" is indeterminate and always "interested"; it was advanced that he and his followers were undermining the seriousness of the American academy. Would the assembled philosophers and literary critics have been capable of drawing a lesson from the accepted indeterminacy, conventionally and by tacit agreement presented as factual truth, that operates and informs the "serious" business that determines the "materiality" of their existence?

The after-dinner speech demands by definition a certain vague euphoria. If you think I have fulfilled that demand only too well, let me hasten to assure you that I am well aware of the complicated organizational assumptions underlying my suggestions. To mention only a few of the heavies: faculty development, fundamental 
curricular revision, overhauling of disciplinary lines until the term "English literary studies" changes drastically in meaning. I am indeed foolhardy enough to look forward to a struggle for such painstaking and painful transformations. But I do not suggest that the struggle should begin at the expense of our students' immediate futures. I think rather that our efforts should be on at least two fronts at once. We should work to implement the changes even as we prepare our students to fit into the job market as it currently exists. It is merely that we should not mistake the requirements of the job market for the ineffable determinants of the nature of literary studies.

To explain what I mean, I will offer you a final example, a diffident and humble one, the description of a course that I found myself designing on my feet-largely because of the predilections I have elaborated so lengthily above. It is a required course for incoming graduate students: Practical Criticism.

You will have gathered that I am deeply doubtful of the isolationist ideology of practical criticism-to explicate the text as such, with all "outside knowledge" put out of play, ${ }^{3}$ even as I think its strategies are extremely useful in interpreting and changing the social text. How can one launch a persistent critique of the ideology without letting go of the strategy? I put together a working answer to the question while I taught the course for the first time.

We begin with a situational definition of "practical criticism": a criticism that allows for departmental qualification for the $\mathrm{PhD}$. (My department no longer has the qualifying examination, but the standards for qualification remain implicitly the same.) A little over the first half of the course is a criticism workshop, where we read each other's work and learn to write in the approved institutional way, trying to cope with its difficulties and to reveal its subtleties. The rest of the course is given to readings and discussions of texts that offer fundamental critiques of the ideology that would present this technique as the description of the preferred practice of the critic-the list can be wide enough to accommodate Percy Shelley, Walter Benjamin, and Michel Foucault. What I hope to achieve through such a bicameral approach is to prepare the student for the existing situation even as I provide her with a mind-set to change it. A very minor individual effort that looks forward to the major collective efforts that are on my mind. ${ }^{4}$

\footnotetext{
${ }^{3}$ I understand and sympathize with that part of the impulse behind New Criticism which wanted to focus attention upon deciphering the text in its context. My point is that, as with my Plan II students, the dominant ideology, slipping in through the back door, has a lot to do with determining a seemingly "free choice"; and that a degree of freedom of choice can be achieved if that determination is recognized.

${ }^{4}$ The effort is minor also because, since we are gathered here together to discuss the problems for our profession, questions of race, sex, and class-the common threads of the social fabric-have had to be laid aside. I am reminded of a two-and-a-half-hour long conversation I had with a group of feminist women and some men on the West Coast earlier this year. Many of them were students of English or French literature. They spoke to me emphatically of an issue of faculty development. Our most prestigious professors, they said, will have nothing to do with so "localized" an issue as "feminism," at least not in the matter of reading the canon. Since we must try to pass our examinations, get recommendation letters, and to get jobs in this impossible market, we write our papers with our feminist consciousness and conscience strangulated, with a deliberate and self-contemptuous cynicism. If an advanced degree in literary studies requires and trains in such divisive compromise, its "humanistic" value comes to very little. Even this is a restricted example. The larger questions-Who can make use of a method such as I outline? Where?-must always loom as immediate correctives for the delusion that "to defend the autonomy of culture [provisionally defined as the total body of imaginative hypothesis in a society and its tradition] seems to me the social task of the 'intellectual' in the modern world" (Northrop Frye, Anatomy of Criticism, p. 127).
} 
I have so far tried to follow the notes of the talk I gave at the ADE Seminar in Iowa City. I would like to end by recalling a moment after the talk. Lawrence Mitchell, chairman of the English department at the University of Minnesota, and a friend of long standing from his graduate student days at the University of Iowa, asked if perhaps my critical attitude did not reflect the fact that I, like him-he was born in England-was an outsider? I have thought about that question. Even after nineteen years in this country, fifteen of them spent in full-time teaching, I believe the answer is yes. But then, where is the inside? To define an inside is a decision, I believe I said that night, and the critical method I am describing would question the ethico-political strategic exclusions that would define a certain set of characteristics as an "inside" at a certain time. "The text itself," "the poem as such," "intrinsic criticism," are such strategic definitions. I have spoken in support of a way of reading that would continue to break down such distinctions, never once and for all, and actively interpret "inside" and "outside" as texts for involvement as well as for change. ${ }^{5}$

${ }^{5}$ If I admit that the simple expression "break down" is doing duty for the hated and feared and derided word "deconstruct," the possibility of reading my speech as being about deconstructive practice in the academy is opened.

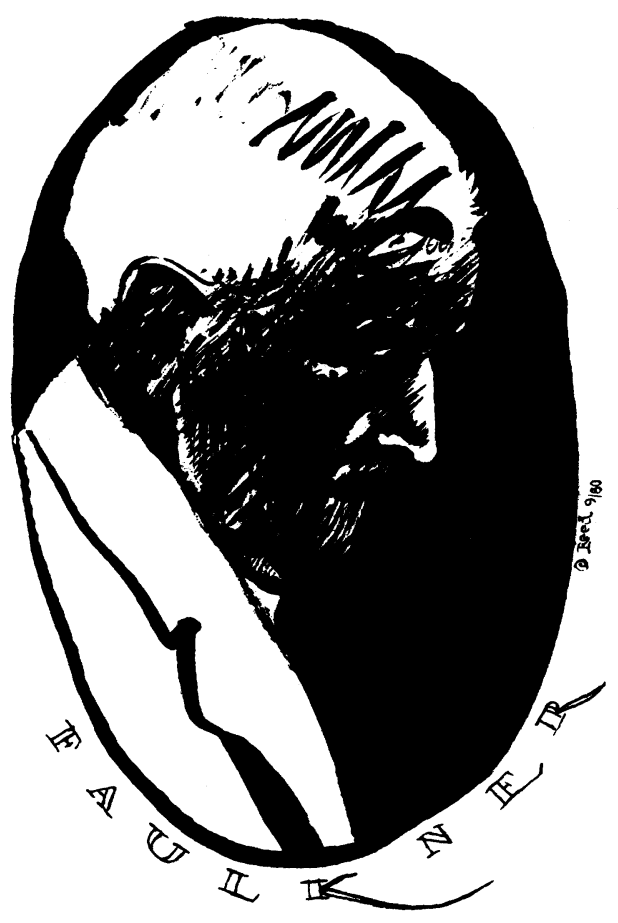

